\title{
Principles of Administrative Trial in Albania
}

\section{Pranvera Xhafaj}

\author{
PhD Candidate at Tirana European University, Tirana, Albania
} veraxhafaj@gmail.com

\section{Doi:10.5901/ajis.2015.v4n1p389}

\section{Abstract}

The Constitution of the Republic of Albania has provided as government order the Parliamentary Republic. This means that our state has decided to support a free democratic regime, excluding any arbitrary or authoritarian rule. Among others, one of the essential elements of the functional democracy is the recognition and enforcement of the requirements of the rule of law's principle. The rule of law is a universal principle. The essence of this principle is to guarantee the fundamental rights and freedoms of individuals. According to the aforementioned principle, the state has the responsibility to act appropriately to safeguard the rights of individuals, which fulfills through the establishment and functioning of the courts. The rights of individuals have subjective character. Violation of those rights, despite the reason, entitles a person to approach the competent authorities to require restitution, or restore them. During the exercise of their authority, these bodies should effectively protect the rights of individuals without prejudice to their rights (Article 1/c of the Law No. 49/2012 "For Administrative Court in Albania"). The most important thing that we have to underline is the fact that the competent authorities (administrative courts), during exercising their competency for defending in effective way the rights of individuals, must apply the law in a right manner, in order not to prejudice the rights of other individuals. This paragraph shall constitute the purpose and objectives of this paper The methodology used is qualitative, comparative and analytical between all the principles of administrative trial, especially in Albania. This paper will serve to other studies of the field ongoing since the Administrative Court is a new court in the Republic of Albania. And for that fact, books or publications in this field are few in number in Albania.

Keywords: principles, trial, court, universal principle, administrative subject.

\section{Independence of administrative courts}

\subsection{Understanding the independence of administrative courts}

The term "Independence of the judicial system" (Article 7 of the Constitution of the Republic of Albania), means "The emancipation of justice agents". Based on this definition, there are two notions that require the necessity of giving a definition and therefore a meaning.

a) Emancipation: The term Emancipation means high professional and moral integrity, impartiality in law enforcement and the avoidance of arbitrariness through providing justice.

b) Agent: The term Agent, means persons named in conformity with legal procedures, charged for the exercise of magistral functions. The issue of independence of the judiciary should bear in mind that at once mentions the foundations of a democratic state of law.

Montesquieu, who is the creator of the concept of judicial independence, thought that its independence achieved through the principle of separation of powers. This universal principle was providing in Article 7 of the Constitution of the Republic of Albania.

The principle of separation of powers has as main goal, the application of liberal and functional democracy, to prevent the possibility of concentration of power in one hand, otherwise known as the principle of unity of power. According to Montesquieu's idea, there is no liberty, if the power of judging isn't separate from the legislative and executive power. This is a fundamental principle because it allows the separation and independence of the judiciary, the political power, which establishes justice by put under the rule of law each subject.

In Article 5 of the draft-law "On the administrative adjudication of disputes and organization of administrative justice" is providing (Article 5, of Law):

"-1.Criteria for appointment and career of judges, their status, responsibility for disciplinary violations, disciplinary measures, disciplinary proceedings, court administration services, as well as judicial reorganization regulated by the law 
No.9877, dated 18.02.2008 "On organization of the judiciary in the Republic of Albania", except for the case when this law provides otherwise."

This provision seems to create favorable conditions for the independence of administrative courts; because the rules that are applying to other courts, will apply to administrative courts unless otherwise stipulated in this Law ("this law", means when this draft law will enter in force). This means that law "On organization of the judiciary in the Republic of Albania", will extend its legal effects to the administrative courts at the same time.

\subsection{Type of independence}

\subsubsection{Jurisdictional independence}

Administrative jurisdictional order can be consider authentic only if the rules of operation and the status of administrative judges is different from that of other judges. Different European countries for example Italy, Germany and France, have administrative jurisdictional order in the literal meaning, because the rules of their functioning are made based on a law other than that of other courts such as civil, or criminal. Based on the foregoing arguments, naturally I raise a question: Is guaranteed an administrative jurisdictional system, under the provisions of Law "On the administrative courts"? From a logical interpretation made in Article 5.1 of the law (cited above), flaring fact that administrative courts will function in accordance with the law on the organization of the judiciary in Albania. This fact brings us therefore logical argument that we are not facing an administrative jurisdictional system (Article $5 \mid 1$ of Law).

\subsubsection{Indipendence from external influences}

The independence of administrative courts achieves through those constitutional elements:

$\checkmark$ Exclusion of hierarchical relations;

$\checkmark$ Publication of judicial decisions;

$\checkmark$ Manner of appointment of judges;

$\checkmark$ Promotion of judges;

$\checkmark$ Discharging from service.

\subsubsection{Exclusion of hierarchical relations}

Article 145/1 of the Constitution of the Republic of Albania, provides: "Judges are independent and subject only to the Constitution and the laws". Based on what is mentioned above, making a literal and logical interpretation at the same time, we conclude that judges have no dependency relations between each other, in the sense that in the process of exercising their competences, they doesn't follow orders, which is a typical phenomenon for hierarchical structures that exist frequently in a working relationship. Find the opportunity to mention the fact that even countries like Germany, Italy, etc, has applied this form of judicial structure, where judges are not obliged to take a decision according to specific order, or on the injunction, but to execute decisions of courts in hierarchic order only.

\subsection{Principle of legitimate interests' protection}

Principles of administrative judgment. The Law that we are analyzing treats two different definitions, such as subjective rights and the legitimate interest. These two rights are so similar to each other, that as late as practicable often were confused between them, like being synonymous to each other. The legal doctrine makes the difference between these two rights, describing them in this way.

"Subjective rights" are rights that relate closely to the subjects of law, while "legitimate interest" is a right that subjects not related closely to the subjects of law. For example, a public administration authority has issued an administrative act addressed to a person " $X$ ", which has made a construction without permission. The subject of the administrative act was "Demolition of construction, made without permission". Next to this construction is another building, which risks bringing down, if the building without permission will demolish. In those conditions, person "Y", the owner of the building that threatens to collapse, is entitled to be addresses to competent authority, requesting the amendment of administrative act, or its abrogation. As noted, the administrative act was not address to " $Y$ ", but to " $\mathrm{X}$ ". Because of this administrative act affects the interests of " $Y$ ", he has the right to dispute the administrative act, because in 
this case his legitimate interest is violated.

\subsection{Right to a fair trial and within reasonable time of judgment}

The right to a fair trial, is one of the most important rights of humans, besides every ones right to life, because it is a right where are summarized many human rights, that are strongly connected with the performance of a judicial process. This right was guarantee by the Constitution of the Republic of Albania in article 42, which stated explicitly that anyone for protecting his constitutional and legal rights, freedoms and interests, has the right to a fair trial. ...

Another source of law, except the Constitution of the Republic of Albania, is the European Convention on Human Rights, which defines the right to a fair trial (Article 42 of the Constitution of the Republic of Albania).

The Article 6 of the Convention stipulates that everyone have the right to a fair and impartial trial, to determinate his rights and civil obligations. In a simple reading of Article 6 of the Convention, the right to a fair administrative trial seems not included in the right to a fair trial process (Article 6 of European Convention for Human Rights).

The European Court of Human Rights, has a court decision, in which Article 6 of the Convention has become an expanded interpretation and it is concluded that part of this right are administrative processes too.

Guaranteeing of this right is provide by the Code of Civil Procedure, which under the provisions of this draft law, will be applied in administrative court proceedings, with the exception of some provisions. According to the definitions made in the Constitution of the Republic of Albania and the International Convention on Human Rights, we conclude that the protection of human rights and fundamental freedoms in domestic judicial processes but also European ones have legal guarantees to be condacted fairly and impartially.

To consolidate the implementation of this principle, the Constitution of the Republic of Albania has assigned the Constitutional Court to guarantee control of a fair trial. An integral part of the right to a fair trial is the development of a trial within a reasonable time. As easily noticed, this principle is not base on fixed deadlines provided. Taking advantage of this space, are numerous cases of violations of the timeliness by the Albanian courts in rendering justice, extending the overlong processes, for various reasons, which can not be considered as legal reasons. To show the importance of this right is sufficient to mention a monumental and historical saying of right and justice, "justice delayed is justice denied". This right is providing in Constitution of the Republic of Albania and in the European Convention on Human Rights.

The Constitution of the Republic of Albania, stated, "Anyone for protection of rights, freedoms and interests of his constitutional and legal ... has the right to a trial .... within a reasonable time". Judicial practice of the European Court of Human Rights in Strasbourg has shown that although reasonable time is subjective, time spent is an objective fact. According to this court when judging a claim for violation of reasonable trial period, take into consideration other factors such as:

a. Complexity of a case;

b. Interest that may be affected;

c. Manner of treating the issue by the judicial authority;

d. Behavior of the claimant, during the trial ...etc;

\subsection{Principle of non-termination of the judgment, due to default of appearance of parties in the process}

The inclusion of this principle in the Law "On the administrative courts", constitutes a deviation from the practice followed so far by the Albanian courts. Civil Procedure Code of the Republic of Albania provides that if the claimant is not present at the hearing to irrational reasons, or for reasons that do not justify the absence of claimant in judgment, entitles the court to cease the trial of claim. Law "On the administrative courts", predicts that the absence of parties at the hearing, does not give rise to dismiss the case.

It is important to note the fact that this principle applies only to written legal acts, which means that it will not break the judgment before we are due to the absence of the parties in the process only to written legal acts. Faced with this legal fact, I raise the question: - Does actions taken from a public administration organ, not in writing manner are the subject of this principle? From a literal and logical interpretation at the same time, that we do to this provision, we conclude that this principle does not apply to non-written acts, which in practice often facing and are different types. This means that raising a claim against a non-written act taken by a public administration organ, as well as the plaintiff's absence without reasonable causes, may empower the court to cease the administrative investigation of the claim. At the same time can be as certain the fact that for written administrative acts, shall not apply forecasting of the Civil Procedure Code to dismiss the case, as it will rely on two basic principles of law: 
a. Lex posterior isderogat lex anterioris.(The latter law revokes the earlier law).

b. A specific law prevails over a general law.

Meanwhile, for the unwritten acts will be implement the provisions of the Civil Procedure Code, regarding the cessation of a trial.

\subsection{Principles of administrative judgment}

\subsubsection{The principle of legitimacy}

This principle requires that the Civil Servant should act in accordance with law, to apply the rules and procedures provisioned in domestic legislation. Civil Servant must be careful especially on taking decisions that affect the rights or interests of individuals, which must necessarily be base and in accordance with legal provisions. The principle of legitimacy requires the public administration to exercise their activity pursuant to the Constitution of the Republic of Albania, international agreements to which Albania has adhered, laws, within the limits of the competencies granted to them and in conformity with the purpose for which these competencies has been granted (Article 9 of Code of Administrative Procedures of the Republic of Albania, 1999).

This principle allows that during administrative proceedings, each competent authority has the discretion to decide according to his free assessment, even without the stated authorization of law, on condition that it is not prohibited.

\subsubsection{Principle of Equity}

Principle of Equity means that no one should be privileged or discriminated because of family origin, sex, race, language, birthplace, political, religious, or cultural pertaining, social and economic conditions (Article 11/1 of Code of Administrative Procedures of the Republic of Albania, 1999).

\subsubsection{Principle of Protection of Public Interest and Citizens Rights}

During the administrative proceeding, public administration bodies, have the obligation to make possible to protect the rights of citizens, as well as the public interest. Those rights may be limited only if it is necessary to apply the principle of proportionality (Article11/2 of Code of Administrative Procedures of the Republic of Albania, 1999).

\subsubsection{Principle of Justice}

The principle of substantive law. Issuance of a fair decision of a public administration organ must have the key condition respecting of the principle of justice. This principle obliges the decision-making body treats equally all the subjects with whom they enter in relation. In an administrative proceeding is required to verify all important facts, in order to guaranty a legitimate and fair to the decision making process (Article 12 of Code of Administrative Procedures of the Republic of Albania, 1999).

\subsubsection{Principle of the right to be hearing of the Interested Parties}

The right of hearing is a general principle of law that characterizes the regularity of a legal process. This is a constitutional principle that extends in all legal proceedings, regardless the object civil, administrative, or criminal. The right of hearing is closely linked to the right of protecting and the right of a fair trial, in order that parties, must have the opportunity to present to the competent authority, legal arguments or written submissions, for resolving their cases as right as it is possible. The right of hearing and the right of protecting cannot be realizing unless the interested parties' doesn't have the right to make written submissions, or give their opinion before the final decision is issue (Article 93 of Code of Administrative Procedures of the Republic of Albania, 1999).

The right of hearing of interested parties is one of the procedural rights of particular importance in an administrative proceeding. This is the reason that this right will be treated from the viewpoint of the European Court of Human Rights and the jurisprudence of the Constitutional Court of Albania. Article 96 of the Code of Administrative Procedure foresees the modalities of the right of hearing during the administrative proceeding (Article 96 of Code of Administrative Procedures of the Republic of Albania, 1999). 
In parenthesis, praising guarantees that this provision has in relation to the right of hearing, declaration of legal positions, of the European Court of Human Rights and the Constitutional Court of Albania, will make that this provision and opportunities to improve it, will be the focus of further discussions. European Court of Human Rights has organically connected party's right to be informed with documentation that is administer by the court, with the guarantee of the right of defense.

Therefore, if the subject argues that he did not become aware of a document or written proof, which brings a direct impact on the quality of defense, then it cannot be repaired by the court, because it is an administrative procedure.

In the large number of decisions that have treated the principle of the right of hearing, I choose as an example the case no.110 / 10, Solvay v Commission, where was order the annulment of the European Commission Decision of 13 December 2000, 2003/5/EC, relating to proceedings under Article 81 of the Treaty. The court argues:

"...the right of defense is a fundamental right, which forms an integral part of the general principles that are guaranteed by the Court... Respecting the right of defense in a proceeding, concerning the establishment of a penalty against a company for violations of Law "On Competition Protection", requires that the decision has to be based on facts presented in the documentation, on the basis of which the Commission is based and supported its claims that there are violations of the Treaty... (Article 81 of the Tractate).

... The right of access to the documents, means that the Commission has to provide to the accused subject, the opportunity to review all documents of the investigation file, in order to make possible his defense. Those should be internal documents and other information considered by the Commission, directly, or indirectly related to the accused, except those documents which intrudes the privacy of other commercial subjects... Violation of the right of access to documents in the proceedings, before the announcement of the court, in principle, may lead, in revocation of this decision, if will be proves that subject's right of hearing was intruded... in this case, the violation can not be corrected, allowing access during court proceedings...

... in fact, the performance of judicial review, limited to the scope of the deposited request, has no effect and does not replace investigation carried out during the practice of administrative proceedings... delayed recognition of certain documents relating to the case under review, has no connection with fact in which situation would be found the subject... ...if we are in a situation where it is noted that the subject is known with the documents during the trial, it is not necessary for subject to prove the fact that he does not know the documentation would bring as result another decision, but to argue that those documents would be useful for his defense..."( Case 110110 Solvay v European Commission )

The Constitutional Court in several decisions has treated the impact of disregard of the right of hearing during the decision-making process, by treating this issue in the context of the right of benign protected.

The Constitutional Court, at decision No.17 /2004argues as follow:

"...referring to the procedural rules, provided for a judge's disciplinary proceedings, as well as the individual's constitutional right to have a fair trial, the High Council of Justice, has violated the applicant's right to be heard and to be protected according to the provisions of Article 42 of the Constitution and Article 6 of the European Convention of Human Rights. In this case, are not implemented the provisions of the Article 96 of Code of Administrative Procedures. At the same time, in this case the Constitutional Court based on the constitutional meaning given to the right to a fair trial (Article 96 of Code of Administrative Procedures of Albania).

The jurisprudence of the European Court of Human Rights and Albanian jurisprudence at the same time have admitted that the essential elements of this right are implement to the court proceedings, both in the parliamentary and administrative procedures. The right to a fair trial appears as a guarantee for citizens, against unfair actions of the government authorities. At the same time, respecting this right, constitutes an obligation that government authorities should not violate the rights and freedoms of citizens, without been ensure to apply regular legal procedures" (Decision no. 17/ 2004 of the Albanian Constitutional Court ).

While at the interpretative decision no. 75/2002, the Constitutional Court stated that:

"...preliminary knowledge of materials that impose on liability a person, whom deals to dismiss, respect of his right to be heard and protected, giving preliminary explanations and arguments during the case, are some basics elements that guarantee the constitutional right of everyone for a fair trial, as a fundamental right. The Constitutional Court's jurisprudence has identified and declared violation of those fundamental rights, as violation of the Constitution". (Decision no. 75/2002 of the Albanian Constitutional Court).

Following the submission of the jurisprudence of the Constitutional Court, in its decision no. 76/2002 was state: 
".... The Parliament, during the procedure followed for the dismissal of the General Attorney, has not complied the respect of those standards. Thus, the Parliament has considered granted all the accusations directed to the claimant, relying only on the discussion of members of Parliamnet, without arguing the concrete violations, without notifying the applicant regularly for the content of the material prepare for it, without giving the time needed for preparation of defense and without hearing it to expound objections about those accusations" (Decision no.76/2002, of the Albanian Constitutional Court).

\section{References}

Çomo, J., "The Administrative Law of the Republic of Albania "The third book, 1983, Tirana.

Floqi, K., "Administration or Dominion Law" The general part, "Vlora" Printing House, 1923, Vlora.

Lamani, A, (1962), "Civil Procedure of People's Republic of Albania", Tirana.

Uka, N (Adv.), Brati, J, (Adv.), 2012, "Magistracy \& Advocacy" "ILARI" P.F. Tirana.

Laws

The Constitution of the Republic of Albania

Administrative Procedure Code of the Republic of Albania, 2009

Civil Procedure Code of the Republic of Albania, 2008

Law no. 49/2012 "On the organization and functioning of Administrative Courts and adjudication of administrative disputes in Albania

\section{Court Decisions}

Decision no. 75/ 2002 of the Albanian Constitutional Court Decision no. 762002 of the Albanian Constitutional Court Decision no. 17/ 2004 of the Albanian Constitutional Court Case 110l10 Solvay v European Commission European Convention for Human Rights 